\title{
Association between secondhand smoking in the home and respiratory morbidity in preschool children
}

\author{
Associação entre tabagismo passivo domiciliar e morbidade respiratória em pré-escolares \\ Asociación entre tabaquismo pasivo domiciliario y morbilidad respiratoria en pre escolares
}

\section{Cecília Helena de Siqueira Sigaud ${ }^{1}$, Ana Barbara de Couto Castanheira², Priscila Costa ${ }^{3}$}

\section{How to cite this article:}

Sigaud CHS, Castanheira ABC, Costa P. Association between secondhand smoking in the home and respiratory morbidity in preschool children. Rev Esc Enferm USP. 206;50(4):562-568. DOI: http://dx.doi.org/10.1590/S0080-623420160000500004

\author{
${ }^{1}$ Universidade de São Paulo, Escola \\ de Enfermagem, Departamento de \\ Enfermagem Materno-Infantil e \\ Psiquiátrica, São Paulo, SP, Brazil. \\ ${ }^{2}$ Instituto do Câncer do Estado de São Paulo \\ Octavio Frias de Oliveira, São Paulo, SP, Brazil. \\ ${ }^{3}$ Universidade Federal de São Paulo, Escola \\ Paulista de Enfermagem, São Paulo, SP, Brazil.
}

\begin{abstract}
Objective: Identifying the prevalence of secondhand smoking in the home and its association with morbidity and hospitalization from respiratory causes in preschool children. Method: This is a cross-sectional study conducted in five early childhood education centers at a public university in São Paulo. Sample size calculation was performed and the participants were randomly determined. Data were collected through questionnaires completed by family members or caregivers of 215 children. Chi-square and Student's t-test were used for the statistical analysis, using a 0.05 significance level. Results: The prevalence of secondhand smoke in the household was $15.3 \%$. Bivariate analysis revealed that secondhand smoke in the household was associated with the occurrence of rapid breathing, subdiaphragmatic retractions in the past three months, and treated ear infections/otitis. Conclusion: A low prevalence of secondhand smoking in the home was found. Secondhand smoke was associated with a higher prevalence of respiratory symptoms and morbidity.
\end{abstract}

\section{DESCRIPTORS}

Tobacco; Smoking; Tobacco Smoke Pollution; Housing; Child, Preschool; Pediatric Nursing. 


\section{INTRODUCTION}

Smoking is considered a major cause of preventable deaths in the world, since it increases the risk of cardiovascular disease, cancer, chronic respiratory diseases, diabetes and premature death. Overall it is responsible for about six million deaths per year, including 600,000 deaths due to secondhand smoke; among these 170,000 occur in children ${ }^{(1-2)}$.

Secondhand smoking is defined as the inhalation of smoke from tobacco products such as cigarettes, cigars, pipes, cigarillos or shisha, by non-smokers who are in daily/ regular contact with smokers in closed spaces ${ }^{(3)}$. The smoke from tobacco products is a dynamic and complex mixture of more than 4,000 chemical agents found either in the form of steam as well as in the form of particles, and is known as environmental tobacco smoke (ETS). Many of these chemicals are known carcinogens and toxic agents ${ }^{(4)}$. This smoke spreads homogeneously in the environment, and contains on average three times more nicotine and carbon monoxide, and up to 50 times more carcinogenic substances than the smoke inhaled by the smoker ${ }^{(3)}$.

Secondhand smoking confers risk to children's health. In $2004,28 \%$ of deaths worldwide attributed to this cause occurred in children ${ }^{(5)}$. Children, especially in early years of life, are a vulnerable population to environmental tobacco smoke. Some reasons for this include their immunological immaturity, narrow and short airways, as well as their long stay in closed places, such as in the household. These characteristics added to other social determinants related to the family's living and working conditions increase the chances of respiratory problems $s^{(2-3,5)}$. In 2011 , respiratory system diseases represented the second leading cause of deaths in Brazil, with pneumonia being the cause for $35.6 \%$ of hospitalizations in children under the age of 5 years ${ }^{(6)}$.

Evidence suggests that secondhand smoke in childhood increases the chances of hospitalization due to asthma, the demand for emergency services ${ }^{(7)}$, wheezing attacks ${ }^{(8)}$, rhinitis symptoms ${ }^{(9)}$, food sensitization ${ }^{(10)}$, caries/cavities in primary dentition ${ }^{(11)}$, atrial fibrillation ${ }^{(12)}$, behavioral problems ${ }^{(13)}$, lower engagement in school activities ${ }^{(14)}$ and lower weight and height gain ${ }^{(15)}$. However, there is a lack of national studies that verify the association between secondhand smoking and respiratory symptoms easily noticeable by family members in preschool children, such as coughing, rapid breathing, "wheezing" and signs of respiratory distress, such as retraction below the ribs.

Knowledge of the consequences of secondhand smoke on children's health condition is crucial because studies show that the majority of parents (59\%) are not aware of the meaning of environmental tobacco smoke or secondhand smoke, and $52 \%$ do not consider their child a passive smoker, or do not believe that the child may suffer respiratory damage as a result of secondhand smoke from family members who live with the child ${ }^{(16)}$.

In addition to the health consequences, secondhand smoke generates costs of approximately $\mathrm{R} \$ 37.4$ million per year, where $R \$ 19.1$ million are related to treatments and hospitalizations in the Brazilian Unified Health System and $\mathrm{R} \$ 18.3$ million are related to the payment of benefits and allowances to the victims' families ${ }^{(3)}$. Considering the infant population, there is evidence that the average annual expenditure on medical expenses is significantly higher in children exposed to environmental tobacco smoke at home, even when the child's parents smoke in an external/open area of the residence ${ }^{(17)}$.

Secondhand smoking is a public health problem, generating impact on both the morbidity and mortality profile of children and in the management of health services. A study of the prevalence of secondhand household smoking and its possible association with respiratory morbidity and hospitalization in children attending early childhood education centers becomes relevant for planning actions to strengthen families and the community in child care. Thus, we aim to contribute with generating evidence in health care to reduce the morbidity and mortality from a preventable cause, to encourage smoke-free environments, and promote the health of children.

This study aims to identify the prevalence of secondhand smoking in the household and its association with symptoms, morbidity and hospitalization for respiratory causes in preschool children. The study hypothesizes that children exposed to secondhand smoke have more episodes of respiratory symptoms and morbidity.

\section{METHOD}

This is a cross-sectional study conducted with those responsible for children enrolled in five early childhood education centers (CEC) of a public university in the state of São Paulo in the period from April to August 2010.

Sample size calculation was based on the prevalence of $37 \%$ of secondhand smoking in the home found in a population-based cross sectional study, with 2,037 children and their respective caregivers in the city of Cuiaba, Mato Grosso, which aimed to estimate the prevalence of secondhand smoke at home ${ }^{(18)}$. Assuming $\alpha$ of $0.05, \beta$ of 0.80 and 95\% confidence interval, this resulted in a sample of 196 subjects. By including an increment of $30 \%$ in the sample size, this equaled 254 individuals, considering the risk of possible losses. Five early childhood education centers had 505 children enrolled. Sampling of the participating children was performed by random selection.

A questionnaire developed by the researchers was used for data collection composed of closed questions according to the research problem. Questionnaires were given to the families who agreed to participate in the study, and were completed by a parent or caregiver. The questions referred to the characteristics of the child, the primary caregiver, the questionnaire respondent, the household and of the economic status of the family, presence of smokers in the household, and history of respiratory symptoms, respiratory morbidity and hospitalization for respiratory causes.

Variables for characterization were: age and gender of the child, relationship (in relation to the child) and education level of the questionnaire respondent, identification of the child's primary caregiver and their education level, number of rooms in the household, and economic 
status. The Brazilian Economic Classification Criterion proposed by the Brazilian Association of Research Companies was adopted for determining economic status ${ }^{(19)}$. This criterion emphasizes an estimate of purchasing power of urban individuals and families, thereby defining economic status, not social class. To do so, the possession of goods (bathrooms, domestic servants, automobiles, personal computers, dishwasher, refrigerator, freezer, washing machine, DVD, microwave, motorcycle, clothes dryer), the level of education of the head of the family and access to public services (piped/city water and paved streets) are considered.

Secondhand smoking was the independent variable studied, defined as the interaction of the child with a family member or another smoker who lives in the same household. The dependent variables included identifying respiratory symptoms in children (coughing, wheezing, rapid breathing, pain or secretion in the ear and retraction below the ribs/subdiafragmatic retraction) in the three months prior to completing the questionnaire, the occurrence of respiratory morbidities (pneumonia, bronchiolitis, treated ear disease/ear infections/otitis, bronchitis or asthma) and hospitalization for any respiratory problem at least once in their lifetime.

Collected data were stored in a Microsoft Excel spreadsheet for Windows 2003 with dual inputs and analyzed in Stata 11.1 software. Descriptive statistics of continuous variables with means and standard deviations were completed. Distribution for both absolute and relative frequencies was performed for categorical variables. Comparison of the proportions for the exposed and unexposed groups to secondhand smoke was performed using Pearson's chi-square test or Fisher's exact test. Student's t-test was used for comparing numerical variables between groups. The prevalence ratio for the outcomes was estimated according to the exposure factors. A 95\% confidence interval was adopted.

The research project was approved by the Ethics Committee of the University of São Paulo Nursing School (Process No. 855/2009). After extensive explanation and clarification of any doubts, all study participants agreed to participate and signed the Clear and Informed Consent form.

\section{RESULTS}

A total of 254 questionnaires were delivered to the families of children attending early childhood education centers during the data collection period. 215 (84.6\%) of those questionnaires were completed, thus comprising the study sample.

Regarding the respondents of the questionnaire, $91.7 \%$ were mothers, $4.2 \%$ were fathers and $4.1 \%$ were children's grandparents. Respondents with higher education predominated $(75 \%)$, followed by those with secondary education (19.9\%) and primary education (2.3\%).

Prevalence of secondhand smoking in the home in the study sample was $15.3 \%$, meaning that 33 children were exposed to secondhand smoke in their domestic environment.

Regarding the period of time that smokers remained in the household, $4.6 \%$ remained in the home for up to 8 hours per day, $87.2 \%$ between 9 and 16 hours per day and $8.2 \%$ for over sixteen hours a day. However, this information was not reported in 20 of the questionnaires.

Concerning the children's characteristics, there was a predominance of males. The minimum age was 4 months old and the maximum was six years and two months. Regarding the primary caregiver of the child, most respondents identified the mother as the primary caregiver (92.4\%), followed by the child's father $(4.2 \%)$, both parents (2.4\%) and grandmothers or caregivers (1\%).

The characteristics of children, families and households according to the presence of secondhand smoking were homogeneous, according to data shown in Table 1.

Table 1 - Characteristics of children, their families and households according to secondhand smoke exposure - São Paulo, SP, Brazil, 2010.

\begin{tabular}{ccc}
$\begin{array}{c}\text { Exposed to } \\
\text { secondhand } \\
\text { smoke }(\mathrm{N}=33)\end{array}$ & $\begin{array}{c}\text { Not exposed } \\
\text { to secondhand } \\
\text { smoke }(\mathrm{N}=182)\end{array}$ & $\begin{array}{c}\mathrm{P} \\
\text { value }\end{array}$ \\
\hline
\end{tabular}

\section{CHILDREN}

Age in years (mean standard deviation)

$$
3.45(1.5) \quad 3.07(1.5)
$$

\section{Gender}

Male

Female

$16(48.5 \%)$

$99(54.4 \%)$

0.53

\section{FAMILIES}

Educational level of the primary caregiver

Secondary education $8(24.2 \%)$

$32(17.9 \%)$

0.39

Higher education

$25(75.8 \%)$

$147(82.1 \%)$

Economic status of the family

A

$5(15.1 \%)$

$30(16.6 \%)$

B1-B2

$25(75.8 \%)$

$140(77.8 \%)$

0.64

C1-C2

$3(9.1 \%)$

$10(5.6 \%)$

Number of rooms in the household

1 to 3

3 or more

Prevalence of respiratory symptoms in the past three months in preschool children was $82.8 \%$. The most frequent respiratory symptom was coughing $(80.8 \%)$, followed by wheezing (31.4\%). Respiratory morbidity was reported as present in 135 (62.8\%) children. The most frequent disorders were ear disease or treated ear infections/otitis in 98 (46\%) children and pneumonia in 54 (25.3\%) children.

In the bivariate analysis (Table 2), secondhand smoking in the home was analyzed for its association to a history of respiratory symptoms, respiratory morbidity and hospitalization for respiratory causes. 
Table 2 - Association between secondhand smoking in the home and the presence of symptoms, morbidity and hospitalization for respiratory causes in children - São Paulo, SP, Brazil, 2010.

\begin{tabular}{|c|c|c|c|c|}
\hline & $\begin{array}{c}\text { Exposed to } \\
\text { secondhand smoke } \\
(\mathrm{N}=33)\end{array}$ & $\begin{array}{l}\text { Not exposed to } \\
\text { secondhand smoke } \\
(N=182)\end{array}$ & $\begin{array}{c}\text { Prevalence ratio } \\
(95 \% \text { confidence } \\
\text { interval) }\end{array}$ & $P$ value \\
\hline \multicolumn{5}{|l|}{ Respiratory symptoms - n(\%) } \\
\hline Coughing & $26(78.8 \%)$ & $146(80.1 \%)$ & $0.97(0.80-1.17)$ & 0.76 \\
\hline Wheezing & $10(31.3 \%)$ & $55(31.4 \%)$ & $0.99(0.56-1.73)$ & 0.98 \\
\hline Pain or secretion in the ear & $2(6.5 \%)$ & $25(14.3 \%)$ & $0.45(0.11-1.81)$ & 0.23 \\
\hline Rapid breathing & $7(22.6 \%)$ & $18(10.4 \%)$ & $2.17(0.98-4.75)$ & 0.05 \\
\hline Retraction below the ribs & $3(9.7 \%)$ & $4(2.3 \%)$ & $4.18(0.98-17.79)$ & 0.03 \\
\hline \multicolumn{5}{|l|}{ Respiratory morbidities - $\mathbf{n}(\%)$} \\
\hline Treated ear disease & $20(62.5 \%)$ & $78(43.1 \%)$ & $1.45(1.05-1.98)$ & 0.04 \\
\hline Pneumonia & $10(30.3 \%)$ & $44(24.4 \%)$ & $1.23(0.69-2.20)$ & 0,48 \\
\hline Bronchiolitis & $3(9.4 \%)$ & $40(22.4 \%)$ & $0.41(0.13-1.27)$ & 0,09 \\
\hline Bronchitis & $2(6.3 \%)$ & $23(12.9 \%)$ & $0.48(0.12-1.96)$ & 0,28 \\
\hline Asthma & $2(6.1 \%)$ & $11(6.1 \%)$ & $0.99(0.23-4.29)$ & 0,99 \\
\hline Hospitalization for respiratory causes $-\mathrm{n}(\%)$ & $4(12.1 \%)$ & $34(18.7 \%)$ & $0.64(0.27-1.7)$ & 0.46 \\
\hline
\end{tabular}

Table 2 data suggest that secondhand smoking in the home was associated with the perception of parents that the child presented rapid breathing or subdiafragmatic retraction/retraction below the ribs in the past three months. Furthermore, these children had a risk between two to four times of presenting these symptoms, respectively. There was a significant difference in the prevalence of treated ear disease between the groups, and children exposed to secondhand smoke in the home presented a 1.4 times higher risk of developing this condition.

Only 38 (17.7\%) households reported at least one hospitalization in a child's life due to breathing problems. Secondhand smoking was not associated with hospitalization for respiratory causes.

\section{DISCUSSION}

There are no safe levels of exposure to environmental tobacco smoke $e^{(5)}$. Data from this study revealed that the prevalence of secondhand smoke in the home among children was $15.3 \%$. Similar results were found in a study conducted in England that evaluated 37,038 children using questionnaires from 1998 to 2012, and revealed a secondhand smoke prevalence of $12.7 \%{ }^{(20)}$. However, other studies have shown a higher prevalence of secondhand smoke in children, ranging from $62.9 \%^{(21)}$ in Portugal to $25.3 \%{ }^{(22)}$ in the United States.

The relatively low prevalence of children exposed to secondhand smoke in the home in this study may be related to a lower prevalence of smoking in the Brazilian population compared to other populations in the world, as well as the predominance of families with higher economic status and level of education. Data from the study "Risk Factor Surveillance and Protection for Chronic Diseases" (Vigilância de Fatores de Risco e Proteção para Doenças Crônicas) carried out through a telephone survey in 2011
(VIGITEL/2011) revealed that the percentage of smokers over 18 years in Brazil was 14.8\%, and that they are more common in populations with lower education levels. The proportion of smokers with less than one year of education or no education was $26 \%$, meaning more than twice that found in the population with over 11 years of schooling $(12 \%)^{(23)}$. The results of a study conducted in Cuiabá with 2,037 children under five years also revealed that the lower the economic level of families, the higher the prevalence of secondhand smoke in the home, being $26.9 \%$ for class $\mathrm{A}$, $26.4 \%$ for class B, $34.9 \%$ for class C, $45.1 \%$ for class D and $47.2 \%$ for class E. Primary caregiver educational level also showed a significant inverse linear trend. When the child's mother only had secondary education, the prevalence of secondhand smoke was $28.4 \%$, and when they had higher education it was only $18.6 \%{ }^{(18)}$.

Corroborating the literature, a study conducted in Brazil, Mexico and Uruguay aimed at identifying the prevalence of smoking according to income and education levels. The results showed that in the period from 1989 to 2008, a reduction in the prevalence of smoking was higher among people with at least 1 year of university/higher education (14.1\%) compared to those with primary education (13\%), or secondary education (12\%). Smoking prevalence was lower among people with higher income. Risk of death from lung cancer, ischemic heart disease, cerebrovascular disease and obstructive pulmonary disease was two times higher among people with less than 8 years of schooling. The results suggest that tobacco control policies had no impact on socio-economic disparities ${ }^{(24)}$.

An outstanding contribution of this study refers to the investigation of secondhand smoking in children belonging to families with stable socio-demographic characteristics and lifestyles. There was a predominance of families belonging to the economic class A or B (93.9\%), who lived 
in homes with more than three rooms (97.2\%), and the primary caregiver of the child had higher education levels $(81.1 \%)$. However, it was observed that despite these characteristics and the low prevalence of smokers (15.3\%), children exposed to smoking in the home showed more symptoms and respiratory problems. In this sense, the analysis of the relationship between the profile of the studied families and respiratory morbidity of children suggests that these factors seem to have a subtle influence on the provision of care that protect children from exposure to tobacco smoke in the home.

Regarding respiratory symptoms, the results of this study show that children exposed to secondhand smoke in the home often presented coughing $(78.8 \%)$, wheezing (31.1\%) or pain/secretion in the ear (6.5\%) within the last three months. A cross-sectional study of 115 children under 5 years of age in Botucatu (SP) showed that among 56 passive smokers, $27.7 \%$ had a cough, $18.3 \%$ chest wheezing and $17.4 \%$ otitis ${ }^{(25)}$.

Secondhand smoking in the home was associated with respiratory symptoms of rapid breathing $(22.6 \%)$ and retraction below the ribs (9.7\%). Rapid, forced or labored breathing, as well as retraction below the ribs or use of accessory muscles for breathing indicate severe respiratory distress and possible impairment of the lower airways. Studies have shown that asthma and bronchitis are associated with secondhand smoke in children, and that secondhand smoke children have an almost twice as high chance of presenting these respiratory problems $s^{(4,7-8,18)}$.

The results of this study suggest that secondhand smoking in the home is also associated with the occurrence of treated ear disease in preschool children, corroborating previous studies ${ }^{(25-26)}$.

Considering these findings, some implications for the practice of health professionals deserve special attention. In order to reduce secondhand smoke in children, it is necessary to establish actions to reduce smoking in the population. The goal set by the World Health Organization is a $30 \%$ reduction in the prevalence of smoking among people aged 15 or more by $2025^{(1)}$.

In 2015, Brazil celebrated 10 years of adherence to the WHO Framework Convention on Tobacco Control (FCTC), the first international public health treaty negotiated under the auspices of the World Health Organization, and which has already been ratified by 178 countries $^{(23)}$. The Framework Convention regulates adopting intersectoral measures in the areas of advertising, publicity, sponsorship, health warnings, secondhand smoking, smoking treatment, illicit trade, prices and $\operatorname{taxes}^{(3)}$.

The measures involve reducing the consumption power of tobacco products by increasing the excise duty on consumption; creating laws to institute completely smoke-free environments in all indoor workplaces, enclosed public places and public transport; warnings about the dangers of smoking through health warnings and campaigns in the media; prohibition of all forms of advertising, promotion and sponsorship of tobacco use; and adopting support measures for those who wish to quit smoking ${ }^{(1)}$.

Far from eliminating the problem, one can consider that Brazil is a country whose policy and control actions for tobacco have achieved satisfactory results, as evidenced by a reduction of the prevalence of smoking over the years. In 1989 , there were $34.8 \%$ of smokers in the population of people 18 years of age or older. In 2013, the National Survey of Health found $14.7 \%(27)$. Considering exposure of the child population to environmental tobacco smoke in the household, intersectoral action for health promotion on individual and collective levels are necessary. These actions should aim at strengthening families for child care, especially regarding respiratory symptoms and problems, as well as promoting tobacco-free environments in the household.

Educational institutions such as the early childhood education centers, in conjunction with the health services, are privileged spaces for sharing information between health professionals, educators, children and their families. The School Health Program (Programa Saúde na Escola - PSE) established by Presidential Decree No. 6286, represents a means of articulation between school and health facilities. Its intersectoral and interdisciplinary actions are intended to establish health promotion practices and the prevention of injuries to Brazilian children, adolescents, young adults and students ${ }^{(28)}$.

In this sense, PSE actions for environmental health promotion could include activities aimed toward children and their families, as well as to education professionals aiming to promote tobacco-free environments in both the household and in the community, preventing smoking commencement, and monitoring of those who wish to reduce or stop with smoking.

Although this study analyzed data from 215 preschool children, some limitations should be considered. The prevalence of secondhand smoking in the home found was lower than that used to calculate the sample size. Future research conducted with socioeconomic profile of families similar to the present study will be able to consider this aspect. Another limitation relates to possible memory bias, since the data is based on questionnaires completed by family members of children and they refer to their health history.

\section{CONCLUSION}

The study found a low prevalence of secondhand smoking in the home among children enrolled in early childhood education centers linked to a public university. The high educational level and economic status of families are child health protection factors. Still, children exposed to secondhand smoke in the home had increased risk of respiratory symptoms such as rapid breathing and subdiafragmatic retraction, as well as respiratory morbidity related to diseases in their ears. Adopting intersectoral actions that coordinate health and education professionals are recommended, aimed at strengthening the family and the community for child health promotion and tobacco-free environments. 


\section{RESUMO}

Objetivo: Identificar a prevalência de tabagismo passivo em domicílio e verificar sua associação com morbidades e hospitalização por causas respiratórias em crianças pré-escolares. Método: Trata-se de estudo transversal conduzido em cinco centros de educação infantil de uma universidade pública de São Paulo. Foi realizado cálculo de tamanho amostral, e a seleção dos participantes foi feita por sorteio. Os dados foram coletados por meio de questionários preenchidos pelos familiares ou cuidadores de 215 crianças. Na análise estatística foram empregados os testes Qui-quadrado e t-Student, considerando-se um nível de significância de 0,05. Resultados: A prevalência de tabagismo passivo em domicílio foi de $15,3 \%$. Verificou-se na análise bivariada que o tabagismo passivo em domicílio esteve associado à ocorrência de respiração rápida, retração subdiafragmática nos últimos três meses, e otite tratada. Conclusão: Verificou-se uma baixa prevalência de tabagismo passivo domiciliar. $\mathrm{O}$ tabagismo passivo esteve associado a uma prevalência maior de sintomas e morbidade respiratória.

\section{DESCRITORES}

Tabaco; Hábito de Fumar; Poluição por Fumaça de Tabaco; Habitação; Pré-Escolar; Enfermagem Pediátrica.

\section{RESUMEN}

Objetivo: Identificar la prevalencia de tabaquismo pasivo en domicilio y verificar su asociación con morbilidades y hospitalización por causas respiratorias en niños pre escolares. Método: Se trata de estudio transversal conducido en cinco centros de educación infantil de una universidad pública de São Paulo. Se realizó cálculo de tamaño de muestra y se hizo la selección de los participantes por sorteo. Los datos fueron recogidos mediante cuestionarios rellenados por los familiares o cuidadores de 215 niños. En el análisis estadístico, se emplearon las pruebas Chi cuadrado y t de Student, considerándose un nivel de significación del 0,05. Resultados: La prevalencia de tabaquismo pasivo en domicilio fue del 15,3\%. Se verificó en el análisis bivariado que el tabaquismo pasivo en domicilio estuvo asociado con la ocurrencia de respiración rápida, retracción subdiafragmática los último tres meses y otitis tratada. Conclusión: Se verificó una baja prevalencia de tabaquismo pasivo domiciliario. El tabaquismo pasivo estuvo asociado con una prevalencia mayor de síntomas y morbilidad respiratoria.

\section{DESCRIPTORES}

Tabaco; Hábito de Fumar; Contaminación por Humo de Tabaco; Vivienda; Preescolar; Enfermería Pediátrica.

\section{REFERENCES}

1. World Health Organization. Noncommunicable diseases and mental health. Global status report on noncommunicable diseases 2014 Geneva: WHO; 2014.

2. Oberg M, Jaakkola MS, Woodward A, Peruga A, PrüssUstün A. Worldwide burden of disease from exposure to second-hand smoke: a retrospective analysis of data from 192 countries. Lancet. 2011;377(9760):139-46.

3. Instituto Nacional de Câncer José Alencar Gomes da Silva. Programa Nacional de Controle do Tabagismo [Internet]. Rio de Janeiro: INCA; 2013 [citado 2016 jan. 9]. Disponível em: http://www2.inca.gov.br/wps/wcm/connect/acoes_programas/site/home/nobrasil/programanacional-controle-tabagismo/programa-nacional

4. Stosic L, Milutinovic S, Lazarevic K, Blagojevic L, Tadic L. Household environmental tobacco smoke and respiratory diseases among children in Nis (Serbia). Cent Eur J Public Health. 2012;20(1):29-32.

5. World Health Organization. Tobacco. Fact sheet no 339 [Internet]. Geneva: WHO; 2015 [cited 2016 Jan 5]. Available from: file:///C:/ Documents\%20and\%20Settings/2509501/Meus\%20documentos/Downloads/WHO\%20Tobacco\%20Fact\%20Sheet.pdf

6. Brasil. Ministério da Saúde. DATASUS. Sistema de Informações sobre Mortalidade - SIM [Internet]. Brasília; 2011 [citado 2015 maio 8 ]. Disponível em: http://www2.datasus.gov.br/DATASUS/index.php?area=060701

7. Wang Z, May SM, Charoenlap S, Pyle R, Ott NL, Mohammed K, et al. Effects of secondhand smoke exposure on asthma morbidity and health care utilization in children: a systematic review and meta-analysis. Ann Allergy Asthma Immunol. 2015;115(5):396-401.

8. Kim JH, Choi JY, Kim NY, Kim JW, Baek JH, Baek HS, et al. Clinical risk factors associated with the development of wheezing in children less than 2 years of age who required hospitalization for viral lower respiratory tract infections. Korean J Pediatr. 2015;58(7):245-50.

9. Shargorodsky J, Garcia-Esquinas E, Navas-Acien A, Lin SY. Allergic sensitization, rhinitis, and tobacco smoke exposure in U.S. children and adolescents. Indoor Air. 2015;5(6):471-6.

10. Thacher JD, Gruzieva O, Pershagen G, Neuman $\AA$, van Hage M, Wickman M, et al. Parental smoking and development of allergic sensitization from birth to adolescence. Allergy. 2016;71(2):239-48.

11. Tanaka K, Miyake Y, Nagata C, Furukawa S, Arakawa M. Association of prenatal exposure to maternal smoking and postnatal exposure to household smoking with dental caries in 3-year-old Japanese children. Environ Res. 2015;143(Pt A):148-53.

12. Dixit S, Pletcher MJ, Vittinghoff E, Imburgia K, Maguire C, Whitman IR, et al. Secondhand smoke and atrial fibrillation: data from the health eHeart study. Heart Rhythm. 2016;13(1):3-9.

13. Chastang J, Baïz N, Cadwallader JS, Robert S, Dywer JL, Charpin DA, et al. Postnatal environmental tobacco smoke exposure related to behavioral problems in children. PLoS One. 2015;10(8):e0133604.

14. Pagani LS, Fitzpatrick C. Early childhood household smoke exposure predicts less task-oriented classroom behavior at age 10. Health Educ Behav. 2015 Nov 13. [Epub ahead of print]

15. Baheiraei A, Shamsi A, Mohsenifar A, Kazemnejad A, Hatmi Z, Milani M, et al. The effects of secondhand smoke exposure on infant growth: a prospective cohort study. Acta Med Iran. 2015;53(1):39-45. 
16. Carvalho RFA, Moraes MKR, Caixeta JCM, Silva JN, Lima AS, Parreira SLS, et al. Percepção dos pais a respeito do tabagismo passivo na saúde de seus filhos: um estudo etnográfico. Rev Paul Pediatr. 2015;33(4):394-9.

17. Batscheider A, Zakrzewska S, Heinrich J, Teuner CM, Menn P, Bauer CP, et al. Exposure to second-hand smoke and direct healthcare costs in children - results from two German birth cohorts, GINIplus and LISAplus. BMC Health Serv Res [Internet]. 2012 [cited 2015 May 05];12:344. Available from: http://www.ncbi.nlm.nih.gov/pmc/articles/PMC3506539/

18. Gonçalves-Silva RMV, Valente JG, Lemos-Santos MGF, Sichieri R. Tabagismo domiciliar em famílias com crianças menores de 5 anos no Brasil. Rev Panam Salud Pub. 2005;17(3):163-9.

19. Associação Brasileira de Empresas de Pesquisa. Critério de Classificação Econômica Brasil, 2015. São Paulo: ABEP; 2015.

20. Jarvis MJ, Feyerabend C. Recent trends in children's exposure to second-hand smoke in England: cotinine evidence from the Health Survey for England. Addiction. 2015; 110(9):1484-92.

21. Vitória PD, Machado JC, Araújo AC, Ravara SB, Samorinha C, Antunes H, et al. Children's exposure to second hand smoke at home: a cross-sectional study in Portugal. Rev Port Pneumol. 2015;21(4):178-84.

22. Homa DH, Neff LJ, King BA, Caraballo RS, Bunnell RE, Babb DS. Vital Signs: disparities in nonsmokers' exposure to secondhand smoke United States, 1999-2012. MMWR Morb Mortal Wkly Rep. 2015;64(4):103-8.

23. Instituto Nacional de Câncer José Alencar Gomes da Silva. Comissão Nacional para Implementação da Convenção-Quadro para controle do Tabaco (CONICQ). Política Nacional de Controle do Tabaco: relatório de gestão e progresso 2011-2012. Rio de Janeiro: INCA; 2014.

24. Costa VLS, Biz A, Waltenberg F, Figueiredo VC, Iglesias R. Impostos sobre o tabaco e políticas para o controle do tabagismo no Brasil, México e Uruguai [Internet]. Rio de Janeiro: ACT/FIOCRUZ; 2013 [citado 2015 maio 05]. Disponível em: http://www.actbr.org.br/uploads/ conteudo/881_act_final_pobreza.pdf

25. Coelho AS, Rocha AS, Jong LC. Consequências do tabagismo passivo em crianças. Ciênc Cuid Saúde. 2012;11(2):294-301.

26. Csákányi, Z, Czinner A, Spangler J, Rogers T, Katona G. (2012). Relationship of environmental tobacco smoke to otitis media (OM) in children. Int J Pediatr Otorhinolaryngol. 2012;76(7):989-93.

27. Fundação Oswaldo Cruz; Instituto Brasileiro de Geografia e Estatística. Pesquisa Nacional de Saúde. Rio de Janeiro: FIOCRUZ/IBGE; 2014.

28. Brasil. Ministério da Saúde; Ministério da Educação. Programa Saúde na Escola. Caderno do gestor do PSE [Internet]. Brasília; 2015 [citado 2016 fev. 12]. Disponível em: http://bvsms.saude.gov.br/bvs/publicacoes/caderno_gestor_pse.pdf 